\title{
Intersectionality and sisterhood in the time of Covid-19
}

\author{
Ai Sumihira, Counties Manukau District Health Board, Aotearoa New Zealand
}

\section{Introduction}

I worked in the acute inpatient Covid-19 ward for about a month between April and May, 2020. This Viewpoint is a reflection on my experience working in such an environment during this period, drawing on some relevant local and international literature to explore the intersectional aspects of social inequalities of race and gender in health. It is noteworthy that the most of teammates I worked with during this period were women, and most of them were women of colour. At the same time, I noted that the importance of women's leadership in the healthcare and science was discussed via many platforms, such as medical journals and at the United Nations. Because of this, the experience of working in healthcare during the pandemic took me on a journey of reviewing and recognising women's resilience and strength. This article will explore some evidence which shows the extent to which the female workforce in healthcare is undervalued at the present time. I also found a number of studies describing strong examples of resilient women acting in times of environmental crises. I will explore how feminisms in social work recognise the diverse experiences of women of colour. Throughout our continuing national experience of Covid-19, social cohesion in Aotearoa has been said to have played a significant role (Spoonley et al., 2020), with the country acting as a "team of five million". While Spoonley et al.'s study (2020) emphasises the importance of social cohesion when it comes to working as a trusted collective, in this article I will argue that our society needs to bounce back to a better and more inclusive norm during the ongoing recovery from Covid-19.

\section{In the time of Covid-19}

Covid-19 is a novel coronavirus that was declared a pandemic by the World Health Organisation (WHO) in March 2020 (United Nations Fund for Population Activities [UNFPA], 2020). A wide range of international outlets have reported that Aotearoa New Zealand has shown solidarity in working to eliminate the virus from spreading during its early stages (Spoonley et al., 2020). In fact, our togetherness was considered to be our greatest strength, and brought us success in minimizing the negative effects of the infection.

During the pandemic, an increase in racial discrimination against Asian peoples has also been reported (Foon, 2020). Indeed, while Aotearoa New Zealand did a great job as a national collective, certain minority groups seem to have experienced severe side-effects of the disease. This tendency of escalating discrimination against Asian people has also occurred elsewhere in the world (Devakumar, Shannon, Bhopal, \& Abubakar, 2020; Farkas \& Romaniuk, 2020). Along with physical attributes, such as advanced age; chronic illnesses such as heart and lung conditions; social determinants, such as poverty; and existing marginalisation have all contributed to worsening one's vulnerabilities during the pandemic (Spoonley et al., 2020).

As a health social worker, I was deployed to an acute Covid-19 inpatient ward for about a month. The hospital quickly made arrangements to have several acute medicine wards allocated for Covid-19 patients, and I was one of two social workers deployed there. Since it was not my usual workplace, I got the chance to work with people whom
AOTEAROA NEW ZEALAND SOCIAL WORK 32(2), 49-54.

CORRESPONDENCE TO: Ai Sumihira ai.sumihira@middlemore. $\operatorname{co.nz}$ 
I would otherwise not have worked with. In spite of the nature of the work and the environment, we were able to quickly bond and became a great team. Everyone seemed to be going the extra mile for our community-helping to alleviate what could have been an especially traumatic experience for our clients and their families. During one busy shift, I just stopped and looked around. Under the layers of personal protection equipment, I realised that the most of team members, including cleaners and tea ladies, were women-indeed, women of colour.

\section{Gendered work}

It has been estimated globally that approximately $70 \%$ of the workforce in health and social service sectors is made up of women (UNFPA, 2020). Alongside this, a crisis like the Covid-19 pandemic is considered to have different effects on men and women. For example, during such emergencies, domestic violence tends to increase. The care needs of the young and elderly are considered as primarily a woman's responsibility in many parts in the world, and these care needs also tend to increase during these emergencies (UNFPA, 2020; Wenham, Smith, \& Morgan, 2020).

A number of scholars report that calamities tend to disadvantage women a lot more than men (Bali et al., 2020; Davis, Harman, Manjoo, Tanyag, \& Wenham, 2019; UNFPA, 2020; Wenham et al., 2020). Despite all of these examples of the differential affects of disasters on men and women, gendered strategies with which to tackle such crises have been negligible (Bali et al., 2020; Davis et al., 2019).

According to Shannon et al. (2019), gender equity is one of the most significant health determinants. Essentially, women make up a substantial part of the workforces deployed during the pandemic and have been working for the safety of all, while their own physical and emotional health and safety are at increased risk. Needless to say, women are already disadvantaged structurally in terms of income and power (Bali et al., 2020; Davis et al., 2019). Gender discrimination at work reportedly leads to reduced productivity, and negatively effects levels of motivation toward work (Shannon et al., 2019). Women tend to be underrepresented in policymaking as well as scholarly publications, particularly in the health sector (Bali et al., 2020; Berlin, Darino, Greenfield, \& Starikova, 2019; UNFPA, 2020). Women of colour tend to be further affected by gender inequity, as their representation in decision-making and scholarly publications is even more scant (Bali et al., 2020). This is even more pertinent to ethnic minorities, sexual minorities and migrant women (Bali et al., 2020; Farkas \& Romaniuk, 2020).

Communities which are perceived as vulnerable or powerless, may not perceive themselves that way. People who are oppressed are not just victims. Some people show incredible strength and resilience during emergency situations (Cook Heffron, Snyder, Wachter, Nsonwn, \& BuschArmendariz, 2016; Jones, Mlcek, Healy, \& Bridges, 2019; Uekusa, 2017). There are a number of studies which highlight the particular strengths of women, especially in the context of the rebuilding phase after a natural disaster.

Drolet et al.'s study (2015) in Pakistan and the United States of America (USA) show that women in local communities stepped up and managed tasks that were generally considered men's work in order to support the community's recovery. In the USA, migrant women collaborated with one another, not only to rebuild their own households but also to help other women, and in fact to help people in the wider community. This study highlighted those women's ability to connect and to act collectively for the benefit of their communities.

Moreover, Jennings, Stanley-Clarke, and Yeung (2018) studied the post-earthquake context of Christchurch in 2010 and 2011, and demonstrated how mothers came together to support each other. Their alliance acted 
as a coping strategy. Similarly, Maidment, Tudor, Campbell, and Whittaker's 2019 study of post-earthquake Christchurch, depicted how women in the community contributed to the city's journey of recovery. For example, women in the community found support for each other through a craft group. Uekusa and Lee (2018) witnessed the strengths of migrant women in Japan after the Tohoku tsunami and earthquake. These migrant women showed extreme strength after such a large-scale natural calamity by being involved in rebuilding activities in the community centres.

Resilience is a contested term, and defining what resilience means is not within the scope of this article; however, all these groups of women certainly had the ability to bounce back with the help of improved social networks. These women certainly found ways to be resourceful in the midst of adversity. These examples call attention to women's ability to connect and build social capital around them, so that they can seek guidance or support from people who are in similar circumstances (Uekusa, 2017).

\section{Feminism, race, intersectionality and social work in the time of Covid-19}

The social work profession also consists of a large number of female workers (Beddoe, 2018). The profession's history and its journey of development has had strong women's involvement throughout (Jones et al., 2019). However, introducing a special issue on women in social work in 2018, Beddoe reported that feminist social work publications in Aotearoa New Zealand have been few and far between in recent decades. Some scholars add to this debate that Western feminism tends to favour middle-class, Western perspectives (Epstein, Hosken, \& Vassos, 2018; Jones et al., 2019; Tedmanson \& Fejo-King, 2016). The literature on feminist social work in Aotearoa is scant, let alone publications written from the perspective of someone from a nondominant culture.
This tendency makes social workers of colour uncomfortable. It disguises the diversity within the profession; however social work practice in Aotearoa has had strong presentation from tangata whenua from the beginning (Staniforth, 2010). Gender is, of course, not the only factor creating inequity. 'Intersectionality' is a term created in the 1990s (Cook Heffron et al., 2016) by Black American feminist Kimberlé Crenshaw (1991). Intersectionality is a concept that helps describe one's positioning and identity within a society by looking at a range of factors, including, for example: class, race, culture, and language. The concept of intersectionality illustrates how power dynamics in a society influence the shaping of one's viewpoint and identity (Mehrotra, 2010). For some women, it is impossible to separate gender and other contributing factors from their ongoing powerlessness in society (Jones et al., 2019). Joy (2019) acknowledges the existing diversity of feminists in Aotearoa, and asserts that social work in Aotearoa needs to build a space for this diversity, particularly for Indigenous women.

Women's experiences in this post-modern world are extremely diverse (Davis et al., 2019; Kapilashrami \& Hankivsky, 2018). My positioning in the society here in Aotearoa would be certainly influenced by Aotearoa's culture, since I am an Asian immigrant. My gaze/viewpoint and identity are changing shapes all the time. I constantly learn from people I come across who bring something to me I did not know. Sometimes it does seem that the way in which society sees me and how I perceive myself are contradictory. On the floor of the acute Covid ward, I witnessed how competent those sisters were. Their ability to care for others in such a challenging environment inspired me to do the same. Their resilience was highlighted during the Covid-19 pandemic. It was such an anxious time for everyone, yet we were able to work collectively and to help each other.

Those debates we have seen so far made me wonder what would happen if we, women 
of diverse backgrounds, collaborate? It seems that working collectively may be one of our strengths. However, through an intersectionality lens with a Covid-19 filter on, I can see that there were more invisible groups who remain unrecognised; however, they too, are competent and resilient.

While we were anticipating the rapid spike of confirmed Covid-19 cases, there was a major concern that Māori were going to get the worst hit by the disease. Our history shows that Māori have had substantial adverse effects from infectious disease and pandemics. The influenza pandemic in 1918 saw a Māori death rate of over $4 \%$, about seven times higher than that of non-Māori (Jones, 2020a). In spite of the perceived higher risk determinants, we saw Māori iwi's pro-active engagement in the community, for example the roadside community service during the Level 4 ilockdown (Ngata, 2020). As a frontline practitioner in the Covid-19 ward, I personally felt very supported by their actions trying to minimise the number of infections by educating the community. However, the roadside community services delivered by local iwi and hapu were unfairly criticised by pundits and political leaders (Ngata, 2020). Moreover, in relation to the Covid-19 response, Māori have been notably absent from the decision-making process within the national health sector (Jones, 2020b).

Ngata (2020) explains that such strengths of Māori to carry out community service for everyone in the community often come from the connections with their ancestors as well as future generations. Stories of the 1918 pandemic were narrated across generations and Māori were not going to repeat the tragedy. Indeed, Ngata (2020) asserts, Māori people have served this community of Aotearoa New Zealand throughout past emergencies and crises. I recall that after the 2019 shooting in Christchurch, Māori community members offered to protect the mosque while Muslim families were praying. I remember that the local marae opened up for survivors after Christchurch earthquakes in 2010 and 2011 (Ngata, 2020). I remember that the marae in Mangere offered shelter for a number of homeless people in 2016 (Boynton, 2018). Those were only examples that were reported. It can be assumed that unrecognised examples of such service provided by Māori communities over crises would be countless.

\section{Sisterhood and social cohesion: An opportunity to change}

A crisis may provide a society with an opportunity to change (Wenham et al., 2020). In fact, simply recovering from the impact on Covid-19 and regaining normality may not be in the nation's - or the social work profession's - best interests. There were some faults in our society that some peoples, such as tangata whenua and women of colour were undervalued and invisible. Aotearoa needs to aim for a better, more inclusive norm than that of our pre-Covid-19 society. Spoonley et al. (2020, p. 5) state that resilience of the society is built upon its "social cohesion". Social cohesion, according to Spoonley et al. (2020), is a community's ability to unite and to form solidarity, and to be inclusive while recognising and valuing difference. Spoonley et al. (2020) assert that social cohesion, or the ability to be collective, should be our new norm for a better sense of wellbeing.

It is clear who may be very good at collective action for community wellbeing. The Māori groups and organisations described earlier are certainly excellent examples to follow (Ngata, 2020; Spoonley et al., 2020). It may also be a strength of women of colour, to connect and raise a sense of togetherness (Cook Heffron et al., 2016). Those groups' perspectives need to be recognised and valued accordingly. I am certain that social workers are in the best place to assist the community with this. We are trained to tackle oppression in the society by empowering people. It may be an important ingredient of our journey of recovery from Covid-19 for us social workers to take time to explore and analyse intersectionality within 
our own profession, and to raise awareness of whose voices may be missing. I was wondering, how long it would take for me to be included in "the team of five million", instead of being an exotic other.

It is widely considered that, by global standards, our government has done an exceptionally a good job in responding to the Covid-19 crisis, I believe it is important to highlight that Aotearoa has a woman leading our government. It seems to me this is another reason to bring more women into leadership roles in the health sector as recommended by a range of scholars (for example, UNFPA, 2020; Bali et al., 2020).

\section{Conclusion}

Aotearoa New Zealand is considered to have done such a remarkable work stopping Covid-19 from spreading extensively. From my perspective, working in the healthcare sector as a frontline professional, I discerned that some groups' work for the community tends to be under-recognised, and this lack of recognition and devaluing appears to be structural. The teammates that I worked with on the floor of the acute Covid ward were mostly women of colour. This article highlights that gender inequity in healthcare needs ongoing discussion and further recognition. At the same time, vigorous activity by Māori iwi and hapu to protect the communities of Aotearoa have been under-recognised. Some scholars suggest that the key to a new state of wellbeing after the Covid-19 period is our ability to work together as a nation (Spoonley et al., 2020). As I have noted, the nation can achieve changeif we can build a safe space to openly discuss inequalities, discrimination and unconscious biases in the society. The effort to eliminate Covid-19 has been such a colourful one, but some of the colours are yet to be recognised.

\section{Note}

i In March 2020 the New Zealand Government announced four levels of alert for the Covid-19 pandemic. These levels specified the actions required and Level 4 was the highest. https://covid19.govt.nz/covid-19/restrictions/ alert-system-overview/

\section{References}

Bali, S., Dhatt, R., Lal, A., Jama, A., Van Daalen, K., \& Sridhar, D. (2020). Off the back burner: Diverse and gender-inclusive decision-making for COVID-19 response and recovery. BMJ Global Health, 5(5) DOI: 10.1136/bmjgh-2020-002595

Beddoe, E. (2018). Women in social work: Practice, policy and research. Aotearoa New Zealand Social Work, 30(3), 1-3. https://anzswjournal.nz/anzsw/article/ view/546

Berlin, G., Darino, L., Greenfield, M., \& Starikova, I. (2019). Women in the healthcare industry. McKinsey Insights, 6(7). Retrieved from https://search-proquest-com. ezproxy.auckland.ac.nz/docview/2374214177?accountid =8424\&rfr_id=info\%3Axri\%2Fsid\%3Aprimo

Boynton, J. (2018). Marae model to support urban homeless touted as possible solution. Radio New Zealand. Retrieved from https://www.rnz.co.nz/news/te-manukorihi/366835/marae-model-to-support-urban-homelesstouted-as-possible-solution

Cook Heffron, L., Snyder, S., Wachter, K., Nsonwn, M., \& Busch-Armendariz, N. (2016). "Something is missing here": Weaving feminist theories into social work practice with refugees. In S. Wendt \& N. Moulding (Eds.), Contemporary Feminisms in Social Work Practice (pp. 166-180).: Routledge.

Crenshaw, K. (1991). Mapping the margins: Intersectionality, identity politics, and violence against women of color. Stanford Law Review, 43(6), 1241-1299.

Davis, S. E., Harman, S., Manjoo, R., Tanyag, M., \& Wenham, C. (2019). Why it must be a feminist global health agenda. The Lancet, 393(2019) 601-603. https://doi.org/10.1016/S0140-6736(18)32472-3.

Devakumar, D., Shannon, G, Bhopal, S. S., \& Abubakar, I. (2020). Racism and discrimination in Covid-19 responses. The Lancet, 395(21231), 1194-1194. https://doi.org/10.1016/S0140-6736(20)30792-3.

Drolet, J., Dominelli, L., Alston, M., Ersing, R., Mathbor, G., \& $\mathrm{Wu}, \mathrm{H}$. (2015). Women rebuilding lives post-disaster: Innovative community practices for building resilience and promoting sustainable development. Gender \& Development, 23(3), 433-448. doi:10.1080/13552074.2 015.1096040

Epstein, S. B., Hosken, N., \& Vassos, S. (2018). Creating space for a critical feminist social work pedagogy. Aotearoa New Zealand Social Work, 30(3), 8-18. Retrieved from https:// anzswjournal.nz/anzsw/article/view/489/594

Farkas, K. J., \& Romaniuk, J. R. (2020). Social work, ethics and vulnerable groups in the time of coronavirus and Covid-19. Society Register, 4(2), 67-82. doi:10.14746/sr.2020.4.2.05

Foon, E. (2020). Spike in racism during pandemic, Human Rights Commission reports. Radio New Zealand. Retrieved from https://www.rnz.co.nz/news/national/415691/spike-inracism-during-pandemic-human-rights-commission-reports

Jennings, A., Stanley-Clarke, N., \& Yeung, P. (2018). Mothers as active contributors to post-earthquake recovery in Christchurch. Aotearoa New Zealand Social Work, 30(3), 19-30.Retrieved from https://anzswjournal. nz/anzsw/article/view/496

Jones, M., Mlcek, S., Healy, J., \& Bridges, D. (2019). Gender dynamics in social work practice and education: A critical literature review. Australian Social Work, 72(1), 62-74. doi:10.1080/0312407X.2018.1524919 
Jones, R. (2020a). Why equity for Māori must be prioritised during the Covid-19 response. The Spinoff. Retrieved from https://thespinoff.co.nz/atea/18-03-2020/whyequity-for-māori-must-be-prioritised-during-the-covid-19 response/

Jones, R. (2020b). Covid-19 and Māori health: "The daily 1pm briefings have been an exercise in Whiteness". The Spinoff. Retrieved from https://thespinoff.co.nz/atea/13-05-2020/ covid-19-and-māori-health-the-daily-1 pm-briefings-havebeen-an-exercise-in-whiteness/

Joy, E. (2019). "You cannot take it with you": Reflections on intersectionality and social work. Aotearoa New Zealand Social Work, 31(1). Retrieved from https://anzswjournal. nz/anzsw/article/view/560

Kapilashrami, A., \& Hankivsky, O. (2018). Intersectionality and why it matters to global health. The Lancet, 391(10140), 2589-2591. doi:https://doi.org/10.1016/ S0140-6736(18)31431-4

Maidment, J., Tudor, R., Campbell, A., \& Whittaker, K. (2019). Women's place-making through craft in postearthquake Christchurch, Aotearoa New Zealand Social Work, 31(1), 17-30. Retrieved from https://anzswjournal. nz/anzsw/article/view/557

Mehrotra, G. (2010). Toward a continuum of intersectionality: Theorizing for feminist social work scholarship. Affilia, 25(4), 417-430. doi:10.1177/0886109910384190

Ngata, T. (2020). COVID-19 and the Māori duty to protect. Overland, May (2020). Retrieved from https://overland. org.au/2020/05/covid-19-and-the-māori-duty-to-protect/ comment-page-1/

Shannon, G., Jansesn, M., Williams, K., Caceres, C., Motta, A., Odhiambo, A., Eleveld, A., \& Mannell, J. (2019). Gender equality in science medicine, and global health: Where are we at and why does it matter? The Lancet, 393(20171), 560-569. doi:https://doi.org/10.1016/S01406736(18)33135-0

Spoonley, P., Gluckman, P., Bardsley, A., Mclntosh, T., Hunia, R., Johal, S., \& Poulton, R. (2020). He oranga hou: Social cohesion in a post-COVID world. Retrieved from https://informedfutures.org/wp-content/uploads/ Social-Cohesion-in-a-Post-Covid-World.pdf

Staniforth, B. (2010). Counselling in social work in Aotearoa New Zealand: The historical, political and socio-cultural evolution. Aotearoa New Zealand Social Work, 22(3), 3-14. doi:10.11157/anzswj-vol22iss3id179

Tedmanson, D, Fejo-King, C. (2016). Talking up and listening well: Dismantling whiteness and building reflexivity. In S. Wendt, \& N. Moulding (Eds.), Contemporary feminisms in social work practice (pp. 149-165). Routledge.

Uekusa, S. (2017). Social vulnerability in disasters: Immigrant and refugee experiences in Canterbury and Tohoku. In W. Waugh \& Z. Han (Eds.). Recovering from catastrophic disaster in Asia (pp. 127-144). Emerald Group Publishing. Retrieved from https://www-emerald-com. ezproxy.auckland.ac.nz/insight/publication/doi/10.1108/ S2040-7262201618

Uekusa, S., \& Lee, S. (2018). Strategic invisibilization, hypervisibility and empowerment among marriage-migrant women in rural Japan. Journal of Ethnic and Migration Studies, 1(18). doi:10.1080/1369183X.2018.1500885

The United Nations Fund for Population Activities. (2020). COVID-19: A Gender lens: protecting sexual and productive health and rights, and promoting gender equality. Retrieved from https://www.unfpa.org/ resources/covid-19-gender-lens

Wenham, C., Smith, J., \& Morgan, R. (2020). Covid-19 is an opportunity for gender equality within the workplace and at home. BMJ Clinical Research Edition, 369 (M1546). doi:10.1136/bmj.m1546 